\title{
Preparation of Chiral Amino Esters by Asymmetric Phase-Transfer Catalyzed Alkylations of Schiff Bases in a Ball Mill
}

\author{
Pierrick Nun,${ }^{[a, b]}$ Violaine Pérez ${ }^{[a]}$ Monique Calmès, ${ }^{[a]}$ Jean Martinez,${ }^{[a]}$ and \\ Frédéric Lamaty*a]
}

\begin{abstract}
The asymmetric alkylation of Schiff bases under basic conditions in a ball mill was performed. The starting Schiff bases of glycine were prepared beforehand by milling protected glycine hydrochloride and benzophenone imine, in the absence of solvent. The Schiff base was then reacted with a
\end{abstract}

halogenated derivative in a ball mill in the presence of $\mathrm{KOH}$. By adding a

Keywords: amino acids $\cdot$ asymmetric synthesis • solid-state synthesis • phase-transfer catalysis • Schiff bases chiral ammonium salt derived from cinchonidine, the reaction proceeded asymmetrically under phase-transfer catalysis conditions, giving excellent yields and enantiomeric excesses up to $75 \%$. Because an equimolar amount of starting material was used, purification was greatly simplified.

\section{Introduction}

The preparation of amino acids in their chiral form remains an ongoing challenge for organic chemists. ${ }^{[1]}$ Used directly for their biological activity or as building blocks for the preparation of peptides, amino acids need to be prepared with well-defined stereochemistry. One approach to their preparation is to use an asymmetric alkylation reaction starting from a glycine derivative. A mild version of this reaction is based on phase-transfer catalysis and Schiff bases of glycine. In the context of amino acid synthesis, this reaction was first developed in 1978 by O'Donnell and co-workers in its non-asymmetric version. ${ }^{[2]}$ In 1989, the same research group developed an asymmetric version using chiral ammonium salts derived from cinchonine or cinchonidine (QX; Scheme 1). ${ }^{[3]}$ Thanks to the work of a number of research groups on the design and synthesis of new chiral catalysts that allow efficient asymmetric induction, ${ }^{[4]}$ the preparation of chiral amino esters, including industrial-scale syntheses, has been achieved. ${ }^{[5]}$ Ball milling is a mechanochemical technique that is widely used to grind minerals into fine particles and to prepare and modify inorganic solids. ${ }^{[6]}$ When performed in the absence of solvent, ball-mill chemistry is also of interest from an environmental point of view.

[a] P. Nun, V. Pérez, M. Calmès, J. Martinez, F. Lamaty Institut des Biomolécules Max Mousseron UMR 5247 Université Montpellier 1

et Université Montpellier 2-CNRS

Place Eugène Bataillon

34095 Montpellier cedex 05 (France)

E-mail: frederic.lamaty@univ-montp2.fr

[b] P. Nun

Current address: LCMT, UMR 6507 ENSICAEN 6

Bd Maréchal Juin 14050 Caen (France)

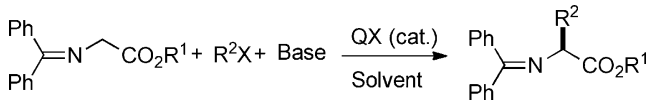

Scheme 1. Classical synthesis of amino acid Schiff bases $(\mathrm{QX}=$ cinchonine or cinchonidine).

In the last few years, this technique has attracted interest for synthetic organic chemistry. ${ }^{[7]}$ In our program dedicated to the development of solvent-free methods in the area of peptide and amino acid chemistry ${ }^{[8]}$ and because, to the best of our knowledge, asymmetric phase-transfer catalysis has not been described in a ball mill, we decided to explore the organocatalyzed reaction of a Schiff base derived from glycine under solvent-free conditions in the presence of chiral ammonium phase-transfer catalysts. This could represent an attractive alternative from the point of view of sustainable development and also an interesting challenge for the development of enantioselective reactions in a ball mill, which have so far been limited to only two different reaction types. ${ }^{[9]}$

\section{Results and Discussion}

Synthesis of the Schiff base: Benzophenone Schiff bases derived from glycine are generally prepared by two methods. The first involves condensing benzophenone and glycine and requires harsh conditions, such as the use of Lewis acid in toluene at reflux with elimination of water with a DeanStark apparatus. ${ }^{[2,10]}$ In this strategy, purification is generally required because concomitant formation of diketopiperazine usually occurs. A milder method, consisting of a transimination reaction of glycine ester hydrochloride with benzophenone imine, has also been developed (Scheme 2). ${ }^{[1]}$ This reaction proceeds at room temperature and the only byproduct is ammonium chloride, which can be easily removed 


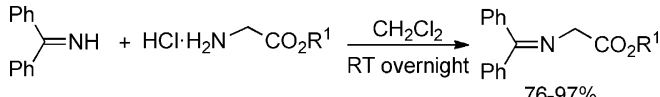

$$
\begin{aligned}
& \mathrm{R}^{1}=\mathrm{Me}, \mathrm{Et}, t \mathrm{Bu}
\end{aligned}
$$

Scheme 2. Synthesis of Schiff bases in solution.

by filtration or aqueous washing. The transimination reaction appeared to be an appropriate reaction for transposition to a ball mill. In a vibratory ball mill, an equimolar amount of the methyl ester of glycine hydrochloride and benzophenone imine was mixed for three hours at $30 \mathrm{~Hz}$ (Scheme 3). This resulted in the exclusive formation of the

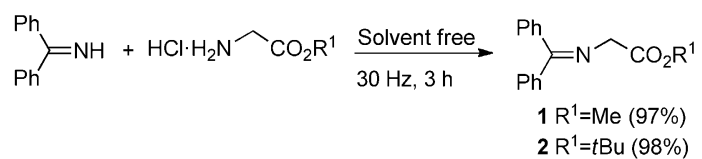

Scheme 3. Solvent-free synthesis of Schiff bases.

expected Schiff base 1, as a white powder, with no remaining starting materials. Aqueous washing eliminated ammonium chloride, and the pure product was obtained without recrystallization in nearly quantitative yield after drying. The reaction time was reduced to three hours compared with one night for the synthesis in solution, and no chlorinated solvent was needed. This method was efficiently extended to the preparation of the Schiff base of the tert-butyl ester. Up to two grams of $\mathbf{1}$ or $\mathbf{2}$ could be easily prepared with this method.

Non-asymmetric alkylation: The first example of a phasetransfer catalysis (PTC) method for the preparation of amino acids was developed in 1978 by O'Donnell et al. Alkylation of the glycine Schiff base ${ }^{[2]}$ was performed in the presence of quaternary ammonium bromide, chloride, or fluoride salts. Bases that have been used include inorganic bases, such as $\mathrm{NaOH}, \mathrm{KOH}, \mathrm{CsOH}$, or $\mathrm{K}_{2} \mathrm{CO}_{3}$ either in solid form or in aqueous solution. Adding a solvent allows the organic molecules to dissolve and can create an additional layer, resulting in a phase interface between the organic and aqueous layer or between the organic and the solid layers. ${ }^{[4 \mathrm{~b}, 12]}$ Whereas these transformations are very important in organic chemistry, few electrophilic alkylation reactions in a ball mill have been described in the literature. ${ }^{[13]}$ First, we decided to test the feasibility of the non-asymmetric version of this reaction. An exploratory study was performed with a vibratory ball mill by mixing Schiff base $\mathbf{1}$, a base, and an alkylating agent $\left(R^{2} X\right.$; Scheme 4$)$. The first

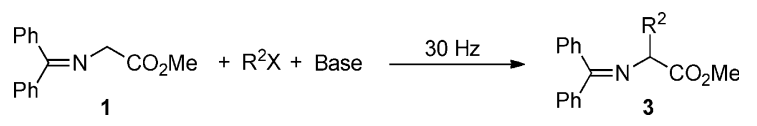

Scheme 4. Non-asymmetric alkylation of a Schiff base.

\begin{tabular}{|c|c|c|c|c|c|}
\hline $\mathrm{R}^{2} \mathrm{X}$ & Base & $\begin{array}{l}\text { Quantity } \\
\text { [equiv] }\end{array}$ & $\begin{array}{l}\text { Time } \\
{[\mathrm{h}]}\end{array}$ & $\begin{array}{l}\text { Conversion } \\
{[\%]}\end{array}$ & $\begin{array}{l}\text { Yield } \\
{[\%]}\end{array}$ \\
\hline $\mathrm{BnBr}$ & $\mathrm{K}_{2} \mathrm{CO}_{3}$ & 3 & 2 & 0 & - \\
\hline $\mathrm{BnBr}$ & $\mathrm{Cs}_{2} \mathrm{CO}_{3}$ & 3 & 1.5 & 100 & 98 \\
\hline $\mathrm{BnBr}$ & $\mathrm{Na}_{2} \mathrm{CO}_{3}$ & 3 & 2 & 0 & - \\
\hline $\mathrm{BnBr}$ & $\mathrm{NaHCO}_{3}$ & 3 & 2 & 0 & - \\
\hline Allylbromide & $\mathrm{Cs}_{2} \mathrm{CO}_{3}$ & 3 & 4.5 & 100 & 98 \\
\hline $\begin{array}{l}\text { 2-Bromomethyl } \\
\text { naphthalene }\end{array}$ & $\mathrm{Cs}_{2} \mathrm{CO}_{3}$ & 3 & 2 & 0 & - \\
\hline $\mathrm{BnBr}$ & $\mathrm{CsOH} \cdot \mathrm{H}_{2} \mathrm{O}$ & 3 & 1 & 100 & $-[\mathrm{a}]$ \\
\hline $\mathrm{BnBr}$ & $\mathrm{CsOH} \cdot \mathrm{H}_{2} \mathrm{O}$ & 1 & 1 & 100 & $-^{[\mathrm{b}]}$ \\
\hline $\mathrm{BnBr}$ & $\mathrm{KOH}$ & 3 & 1 & 100 & 92 \\
\hline Allylbromide & $\mathrm{KOH}$ & 3 & 1 & 100 & 96 \\
\hline $\begin{array}{l}\text { 2-Bromomethyl } \\
\text { naphthalene }\end{array}$ & $\mathrm{KOH}$ & 3 & 1 & 100 & 92 \\
\hline $\mathrm{BnBr}$ & $\mathrm{K}_{2} \mathrm{CO}_{3}$ & 3 & 2 & 0 & - \\
\hline
\end{tabular}

Table 1. Optimization of the base.

[a] Product not isolated due to partial hydrolysis of the ester. Proportion ester/acid 80:20. [b] Product not isolated due to partial hydrolysis of the ester. Proportion ester/acid 78:22.

step involved optimizing the applied base, starting with carbonates, which are the most easily handled solid bases (Table 1). Among the carbonate bases tested, only cesium carbonate mediated the alkylation of glycine imine with benzyl or allyl bromide, but was inefficient with 2-bromomethyl naphthalene. Cesium hydroxide was also efficient and, in each experiment, the presence of the corresponding free acid (ca. 20\%), resulting from the hydrolysis of the ester, was detected. This process occurred even when the amount of base was decreased or when a drying agent, such as magnesium sulfate, was included. Very often used under classical conditions, potassium hydroxide provided the expected products. It is interesting to note that, consistent with reactions performed in solution, exclusive monoalkylation occurred. The $\mathrm{p} K_{\mathrm{a}}$ of the alkylated product is probably higher than that of the starting Schiff base ${ }^{[14]}$ and $\mathrm{KOH}$ is not a sufficiently strong base to achieve deprotonation under solvent-free conditions. The next step of our work was to study the asymmetric version of this reaction.

Asymmetric alkylation: The first objective of this study was to delineate the optimum reaction conditions to obtain full conversion with high enantiomeric excess. A number of parameters were varied to optimize the reaction: the nature of the catalyst, base, and vibration frequency of the ball mill. This evaluation was performed on a model reaction. Catalysts 4-7 derived from cinchonidine, which have previously been described in the literature, were prepared by successive alkylation reactions. Attempts to perform these reactions in the ball mill failed, therefore, the catalysts were prepared according to literature procedures (Scheme 5). ${ }^{[15]}$ For the enantioselective reaction, two reaction pathways were considered after initial formation of the enolate: either direct alkylation without interaction between the enolate and the catalyst, or an alkylation after complexation of the enolate with the catalyst. The first pathway leads to the racemic product, whereas the second should predominantly produce one enantiomer selectively. In the course of the study of the 

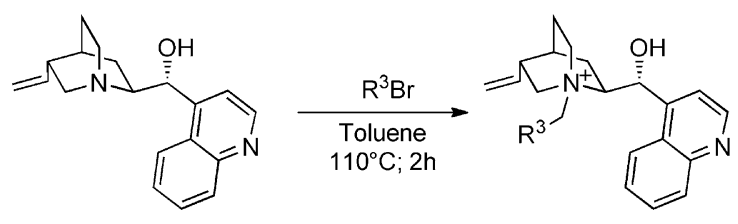

$4 \mathrm{R}^{3}=$ phenyl $91 \%$

$5 \mathrm{R}^{3}=$ anthracene $89 \%$

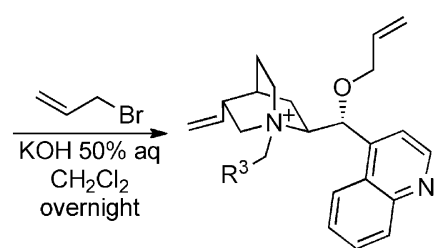

$6 \mathrm{R}^{3}=$ phenyl $97 \%$

$7 R^{3}=$ anthracene $92 \%$

Scheme 5. Preparation of phase-transfer catalysts from cinchonidine.

non-asymmetric reaction, we found that some bases did not lead to the formation of the expected product in the absence of catalyst (Table 1). Our expectation was that these bases might be reactive in the presence of the phase-transfer catalyst and yield one enantiomer preferentially. Consequently, as a preliminary study, these bases were tested in the presence of catalyst $\mathbf{7}$, which is known to give the best result under classical conditions; unfortunately, adding this catalyst did not improve the conversion when the reactions were not effective in the non-asymmetric version. Consequently, $\mathrm{KOH}$, which was the most efficient base in the non-asymmetric reaction, was used in subsequent experiments. The model reaction that was chosen is presented in Table 2, and

Table 2. Evaluation of the catalysts.

\begin{tabular}{|c|c|c|c|c|}
\hline$\underset{\mathrm{Ph}}{\mathrm{Ph}}=\mathrm{N}$ & $+\sim^{B r}$ & $\begin{array}{r}+\mathrm{KOH} \\
\quad(3 \text { equiv) }\end{array}$ & $\underset{\substack{\text { Catalyst } \\
(10 \mathrm{~mol} \%)}}{\stackrel{\text { Ball mill }}{\longrightarrow}}$ & \\
\hline Entry & Catalyst [\%] & & e.r..$^{[a, b]}$ & $e e[\%]^{[\mathrm{a}]}$ \\
\hline 1 & $4(10)$ & & $52: 48$ & 4 \\
\hline 2 & $5(10)$ & & $61: 39$ & 22 \\
\hline 3 & $6(10)$ & & $66: 34$ & 32 \\
\hline 4 & $7(10)$ & & $79: 21$ & 58 \\
\hline 5 & $7(20)$ & & $76: 24$ & 53 \\
\hline 6 & $7(30)$ & & $78: 22$ & 58 \\
\hline
\end{tabular}

[a] Determined by HPLC analysis of the Marfey derivative. [b] e.r. = enantiomeric ratio.

was performed with a mixture of Schiff base 2, allyl bromide, and $\mathrm{KOH}$. The solid mixture was ball milled in the presence of a phase-transfer catalyst to yield the protected allylglycine. Four catalysts 4-7 were used in the same amounts commonly used in PTC $(10 \mathrm{~mol} \%)$. The frequency of the ball mill was set at $30 \mathrm{~Hz}$ (Table 2). The reactions were carried out with the Schiff base of glycine tert-butyl ester 2, because the use of the corresponding methyl ester yielded the hydrolyzed product (ca. 10\%) together with the expected product under these conditions. The enantiomeric excess of the products were evaluated by hydrolyzing the Schiff base of the synthesized amino esters and preparing the corresponding Marfey derivatives, ${ }^{[16]}$ which were analyzed by HPLC. The HPLC profiles of the reaction mixtures obtained from the enantioselective experiments were then compared to those of the racemic mixture. This method is more general than the use of chiral HPLC. The third gener- ation catalysts 6 and 7 (Table 2, entries 3 and 4) were more efficient, with catalyst $\mathbf{7}$, being the most hindered, producing the highest enantiomeric excess. This ranking is similar to that obtained in solution. Increasing the amount of catalyst (Table 2, entries 5 and 6) did not significantly improve the enantiomeric excess.

The second parameter that was analyzed was the influence of the frequency of ball mill vibration on the enantioselectivity. The kinetics of the reaction could be decreased by slowing down the milling, which could allow time for the enolate of the Schiff base to chelate the chiral catalyst. Under these conditions, the alkylating agent may react preferentially on one of the two sides of the complex. If the reaction between the enolate and the electrophile is too fast, the complex would not have time to exist and both of the two possible products would be generated, without stereoselectivity. However, the results obtained under a range of frequencies did not show significant differences for the measured enantiomeric excess (Table 3). From 30 to $20 \mathrm{~Hz}$, the

Table 3. Influence of the ball-mill frequency of vibration on the alkylation reaction catalyzed by $7(10 \%)$ in the presence of KOH (3 equiv).

\begin{tabular}{llll}
\hline Entry & Frequency $[\mathrm{Hz}]$ & e.r. $^{[\mathrm{a}]}$ & $e e[\%]^{[\mathrm{a}]}$ \\
\hline 1 & 30 & $79: 21$ & 58 \\
2 & 20 & $82: 18$ & 64 \\
3 & 10 & $82: 18$ & 64 \\
\hline
\end{tabular}

[a] Determined by HPLC analysis of the Marfey derivative.

excess was increased by $6 \%$, but remained the same from 20 to $10 \mathrm{~Hz}$; the optimum frequency was found to be $20 \mathrm{~Hz}$. The amount of base was an important factor in controlling the enantioselectivity of the reaction. By decreasing this amount, the quantity of enolate generated should be less significant at any time of the reaction, and the substrate should be more prone to interaction with the phase-transfer catalyst to generate a single enantiomer. By decreasing the amount of base to two equivalents, the enantiomeric excess was clearly improved, up to $75 \%$ (Table 4 ); however, fur-

Table 4. Influence of the quantity of $\mathrm{KOH}$ on the alkylation reaction catalyzed by $\mathbf{7}(10 \%)$ in a ball mill operated at $30 \mathrm{~Hz}$.

\begin{tabular}{llll}
\hline Entry & KOH [equiv] & e.r. $^{\left[{ }^{[a]}\right.}$ & ee [\%] $]^{[\mathrm{a}]}$ \\
\hline 1 & 3 & $79: 21$ & 58 \\
2 & 2 & $87: 13$ & 75 \\
2 & 1 & $86: 14$ & 73 \\
\hline
\end{tabular}

[a] Determined by HPLC analysis of the Marfey derivative. 
ther decreasing the amount of base to one equivalent did not improve the enantiomeric excess.

Examples: The results described here provided us with the optimum parameters for the reaction with allyl bromide, which could be applied to other electrophiles (Table 5). A range of electrophiles, both liquid and solid, were used. Aminoesters with enantiomeric excesses varying from $36-75 \%$ could be prepared (Table 5). In each case, conversion was complete and yields were excellent, however, the enantiomeric excesses obtained were generally lower than those obtained under PTC conditions in the presence of solvents. Nevertheless, these examples demonstrate that it is possible to develop asymmetric syntheses in a ball mill, despite a high concentration of reactants and difficulties associated with temperature control. Literature reports suggest that the use of derivatives of cinchonidine provides mainly the $(S)$ enantiomer of the amino ester $^{[4]}$ This was checked for the solvent-free version of the reaction by measuring the optical rotation, which, in each example presented above, was negative, in agreement with the data obtained from reactions performed under classical conditions. This conclusion was further confirmed in the case of product 12 by comparing the HPLC chromatogram with that obtained from an authentic sample of Lphenylalanine. Furthermore, because an equimolar amount of starting material was used, the purification step was facilitated.

Mechanism: In the asymmetric alkylation described herein, Schiff base 2, the base $(\mathrm{KOH})$, and the phase-transfer catalyst $\mathbf{7}$ are solids, whereas the alkylating agent is either a liquid or a solid. In the absence of any solvent, organic or aqueous, the reaction mechanism is expected to be distinct, even if a reactant in the liquid phase could play the role of solvent, albeit in small quantities. The situation is quite different when all reactants are solid, as is the case in the synthesis of amino esters 13 or 16. This was not detrimental to the reaction because one of the best ee values was obtained $(75 \%)$ in this case. Consequently, solid-solid reactions can be very efficient.

The first step of the reaction involves deprotonation of the starting Schiff base by KOH. This step presumably takes place at the interface between the two solids to form a potassium enolate. No degradation of the Schiff base or of 2-bromomethylnaphthalene was detected by ${ }^{1} \mathrm{H}$ NMR spectroscopic analysis. The chiral catalyst should then be able to interact with the enolate and induce the enantioselectivity by reaction with the electrophile on a preferential face. In contrast to classical phase-transfer catalysis, the catalyst was not necessary for the reaction. We have
Table 5. Enantioselective alkylations in a ball mill.

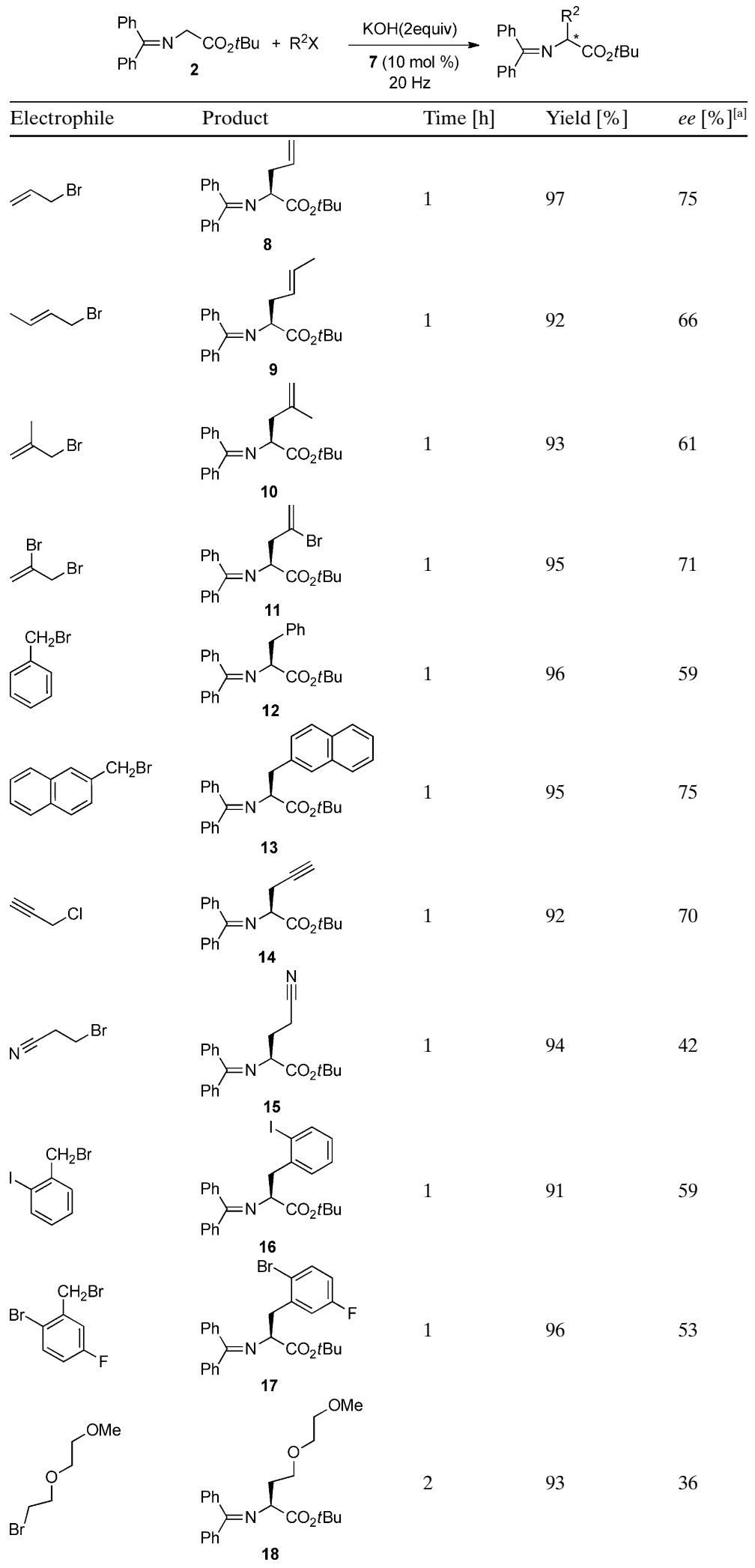

[a] Determined by HPLC analysis of the Marfey derivative.

demonstrated in this study that, in the absence of catalyst, the non-asymmetric version of the reaction gave good re- 
sults and the reaction time was similar to that observed in the presence of a catalyst. This should not favor the formation of one enantiomer because the formed enolate could react immediately with the alkylating agent. Nevertheless, the $e e$ values that were observed are high when the difference in quantities of base ( 2 equiv), alkylating agent ( 1 equiv), and phase transfer catalyst ( 0.1 equiv) are taken into account. These results might be explained by the existence of different phases, which determine the step sequence in which the reaction takes place ${ }^{[17]}$ It is also possible that melting of some of the reactants may provide a liquid medium in which the reaction can occur. ${ }^{[9 \mathrm{c}]}$

\section{Conclusion}

The asymmetric preparation of amino esters by using a phase-transfer catalyzed transformation in a ball mill was studied. Conversions and yields were excellent and various parameters were explored to find the optimal conditions for achieving high enantiomeric excess (up to $75 \%$ ). Although the enantiomeric excess values were lower than those obtained in solution, these promising results will nurture further studies in this area in our laboratory.

\section{Experimental Section}

The ball-milling experiments were performed in a Retsch MM200 mixer mill (Retsch GmbH, Haan, Germany) with two stainless balls at RT.

${ }^{1} \mathrm{H}$ and ${ }^{13} \mathrm{C}$ NMR spectra were recorded on a Bruker Avance- $300 \mathrm{MHz}$ spectrometer. HRMS analyses were performed on a Q-Tof (Waters, ESI, 2001) spectrometer. Marfey derivatives were analyzed on a Beckman Coulter HPLC using a Symmetry Shield column with a linear gradient of acetonitrile in water from 0 to $20 \%$ in 20 minutes.

\section{Typical procedure for the preparation of Schiff bases}

Methyl N-(diphenylmethylene)glycinate (1): Glycine methyl ester $(6.14 \mathrm{mmol}, 1.029 \mathrm{~g})$ and benzophenone imine $(6.14 \mathrm{mmol}, 1.03 \mathrm{~mL})$ were introduced into a $10 \mathrm{~mL}$ grinding jar with two stainless steel balls $(7 \mathrm{~mm}$ diameter). The grinding jar was then rotated at $30 \mathrm{~Hz}$ for $3 \mathrm{~h} . \mathrm{Et}_{2} \mathrm{O}$ was added to the jar and the solution was washed with water then dried over $\mathrm{MgSO}_{4}$ and concentrated under vacuo to obtain $1(1.51 \mathrm{~g}, 97 \%)$ as a white powder. M.p. $41^{\circ} \mathrm{C} ;{ }^{1} \mathrm{H}$ NMR $\left(300 \mathrm{MHz}, \mathrm{CDCl}_{3}\right): \delta=3.76(\mathrm{~s}, 3 \mathrm{H})$, $4.24(\mathrm{~s}, 2 \mathrm{H}), 7.18-7.24(\mathrm{~m}, 2 \mathrm{H}), 7.31-7.47(\mathrm{~m}, 3 \mathrm{H}), 7.49-7.53(\mathrm{~m}, 3 \mathrm{H})$, $7.68 \mathrm{ppm}(\mathrm{dd}, J=6.2,1.5 \mathrm{~Hz}, 2 \mathrm{H}) ;{ }^{13} \mathrm{C} \mathrm{NMR}\left(300 \mathrm{MHz}, \mathrm{CDCl}_{3}\right): \delta=52.0$, 55.6, 127.7, 128.1, 128.9, 130.5, 135.9, 139.2, 171.1, 172.0 ppm; MS (ESI): $m / z: 254.0[M+\mathrm{H}]^{+}$.

tert-Butyl-N-(diphenylmethylene)glycinate (2): By using the same procedure described for $\mathbf{1}$, product $\mathbf{2}$ was obtained as a white powder $(1.77 \mathrm{~g}$, $98 \%$ ). M.p. $113^{\circ} \mathrm{C} ;{ }^{1} \mathrm{H}$ NMR $\left(300 \mathrm{MHz}, \mathrm{CDCl}_{3}\right.$ ): $\delta=1.49$ (s, $\left.9 \mathrm{H}\right), 4.15$ (s, 2H), 7.16-7.24 (m, 2H), 7.31-7.43 (m, 3H), 7.44-7.52 (m, 3H), 7.69 ppm $(\mathrm{dd}, J=6.8,1.6 \mathrm{~Hz}, 2 \mathrm{H}) ;{ }^{13} \mathrm{C} \mathrm{NMR}\left(300 \mathrm{MHz}, \mathrm{CDCl}_{3}\right): \delta=28.1,56.3$, 81.0, 127.8, 128.0, 128.6, 128.8, 130.4, 136.2, 139.4, 169.8, 171.52 ppm; MS (ESI): $m / z: 296.2[M+\mathrm{H}]^{+}$.

Typical procedure for the preparation of catalysts CTP 4 and 5: Benzyl bromide $(13.9 \mathrm{mmol}, 1.66 \mathrm{~mL})$ or 9-(chloromethyl)anthracene $(3.15 \mathrm{~g}$, $13.9 \mathrm{mmol})$ was added to a solution of cinchonidine $(13.3 \mathrm{mmol}, 3.91 \mathrm{~g}$ ) in toluene $(40 \mathrm{~mL})$ and the solution was heated to reflux for $2 \mathrm{~h}$. After cooling the solution to RT, diethyl ether $(200 \mathrm{~mL})$ was added to yield a yellow precipitate that was isolated by filtration. Concentration and crystallization of the mother liquor in a diethyl ether/dichloromethane mixture yielded a second crop of the expected product.
$N$-Benzylcinchonidinium bromide CTP (4): ${ }^{[18]}$ M.p. $123^{\circ} \mathrm{C}$ (lit. $118^{\circ} \mathrm{C}$ ); ${ }^{1} \mathrm{H}$ NMR $\left(300 \mathrm{MHz}, \mathrm{CDCl}_{3}\right): \delta=0.95-1.11(\mathrm{~m}, 1 \mathrm{H}), 1.10-1.32(\mathrm{~m}, 1 \mathrm{H})$, $1.52-1.69(\mathrm{~m}, 4 \mathrm{H}), 1.78-1.95(\mathrm{~m}, 2 \mathrm{H}), 1.98-2.13(\mathrm{~m}, 1 \mathrm{H}), 2.35-2.52(\mathrm{~m}$, $1 \mathrm{H}), 3.07-3.20(\mathrm{~m}, 2 \mathrm{H}), 3.78(\mathrm{~d}, J=12.8 \mathrm{~Hz}, 1 \mathrm{H}), 4.07(\mathrm{t}, J=9.4 \mathrm{~Hz}$, $1 \mathrm{H}), 4.52-4.72(\mathrm{~m}, 1 \mathrm{H}), 4.91(\mathrm{~d}, J=11.2 \mathrm{~Hz}, 1 \mathrm{H}), 5.11-5.28(\mathrm{~m}, 1 \mathrm{H})$, $5.31-5.52(\mathrm{~m}, 1 \mathrm{H}), 5.66(\mathrm{~d}, J=11.9 \mathrm{~Hz}, 1 \mathrm{H}), 5.72(\mathrm{~d}, J=11.9 \mathrm{~Hz}, 1 \mathrm{H})$, $6.56(\mathrm{~s}, 2 \mathrm{H}), 7.18-7.25(\mathrm{~m}, 5 \mathrm{H}), 7.68-7.73(\mathrm{~m}, 3 \mathrm{H}), 7.77-7.82(\mathrm{~m}, 1 \mathrm{H})$, $8.12(\mathrm{~d}, \quad J=9.0 \mathrm{~Hz}, 1 \mathrm{H}), 8.83 \mathrm{ppm} \quad(\mathrm{d}, J=4.5 \mathrm{~Hz}, 1 \mathrm{H}) ;{ }^{13} \mathrm{C} \mathrm{NMR}$ $\left(300 \mathrm{MHz}, \mathrm{CDCl}_{3}\right): \delta=22.5,25.0,26.3,38.0,50.3,59.9,62.2,65.1,67.3$, $117.8,119.9,123.0,123.7,127.0,127.4,128.5,128.7,129.5,130.0,134.1$, 136.0, 144.7, 147.1, 149.4 ppm; MS (ESI): $m / z: 385.3[M+\mathrm{H}]^{+}$.

$N$-Anthracenylmethylcinchonidinium chloride CTP (5): $:^{[15]}$ M.p. $165^{\circ} \mathrm{C}$ (lit. $\left.168^{\circ} \mathrm{C}\right) ;{ }^{1} \mathrm{H} \mathrm{NMR}\left(300 \mathrm{MHz}, \mathrm{CDCl}_{3}\right): \delta=0.99-1.29(\mathrm{~m}, 2 \mathrm{H}), 1.61-2.04$ $(\mathrm{m}, 5 \mathrm{H}), 2.05-2.19(\mathrm{~m}, 1 \mathrm{H}), 2.47(\mathrm{t}, J=12.1 \mathrm{~Hz}, 1 \mathrm{H}), 2.59$ (dd, $J=11.0$, $12.4 \mathrm{~Hz}, 1 \mathrm{H}), 4.00(\mathrm{~d}, J=13.1 \mathrm{~Hz}, 1 \mathrm{H}), 4.62-4.83(\mathrm{~m}, 2 \mathrm{H}), 4.91(\mathrm{~d}, J=$ $10.4 \mathrm{~Hz}, 1 \mathrm{H}), 5.22(\mathrm{~d}, J=17.4 \mathrm{~Hz}, 1 \mathrm{H}), 5.35-5.51(\mathrm{~m}, 1 \mathrm{H}), 6.72(\mathrm{~m}, 2 \mathrm{H})$, 7.02-7.29 (m, 4H), 7.42 (dd, $J=6.7,7.7 \mathrm{~Hz}, 1 \mathrm{H}), 7.58-7.69(\mathrm{~m}, 2 \mathrm{H}), 7.76$ $(\mathrm{d}, J=8.1 \mathrm{~Hz}, 1 \mathrm{H}), 8.03(\mathrm{~s}, 1 \mathrm{H}), 8.07(\mathrm{dd}, J=4.5 \mathrm{~Hz}, 1 \mathrm{H}), 8.19(\mathrm{~d}, J=$ $5.0 \mathrm{~Hz}, 1 \mathrm{H}), 8.75(\mathrm{~d}, J=9.0 \mathrm{~Hz}, 1 \mathrm{H}), 8.81-8.89(\mathrm{~m}, 2 \mathrm{H}), 9.00 \mathrm{ppm}(\mathrm{d}, J=$ $8.5 \mathrm{~Hz}, 1 \mathrm{H}) ;{ }^{13} \mathrm{C}$ NMR $\left(300 \mathrm{MHz}, \mathrm{CDCl}_{3}\right): \delta=23.5,25.6,25.8,38.4,50.2$, $54.6,61.2,66.6,67.4,117.6,118.1,120.0,124.1,124.2,124.6,124.7,125.4$, $126.4,126.7,127.3,127.5,128.2,128.3,128.6,129.0,130.1,130.3,131.0$, $132.6,133.1,136.4,145.7,147.0,149.2 \mathrm{ppm} ;$ MS (ESI): $\mathrm{m} / \mathrm{z}: 486.4$ $[M+\mathrm{H}]^{+}$

General procedure for the preparation of catalysts CTP 6 and 7: Allylbromide ( $28.9 \mathrm{mmol}, 2,5 \mathrm{~mL}, 3$ equiv) then $50 \% \mathrm{KOH}$ aqueous solution $(47 \mathrm{mmol}, 5 \mathrm{~mL})$ were added to a solution of CTP 2 or $4(9.50 \mathrm{mmol})$ in dichloromethane $(40 \mathrm{~mL})$. The reaction mixture was stirred at RT overnight then diluted with water $(50 \mathrm{~mL})$ and extracted with dichloromethane $(3 \times 50 \mathrm{~mL})$. The combined organic extracts were dried over $\mathrm{MgSO}_{4}$, filtered, and concentrated in vacuo to give a yellow oil. Crystallization from a diethyl ether/methanol mixture at $-20^{\circ} \mathrm{C}$ gave the desired product as a yellow powder.

O-(9)-Allyl-N-9-benzylcinchonidinium bromide CTP $(6)::^{[19]}$ M.p. $148^{\circ} \mathrm{C}$ (lit. $\left.145-148^{\circ} \mathrm{C}\right) ;{ }^{1} \mathrm{H}$ NMR $\left(300 \mathrm{MHz}, \mathrm{CDCl}_{3}\right): \delta=1.25(\mathrm{~s}, 1 \mathrm{H}), 1.62-1.98$ $(\mathrm{m}, 3 \mathrm{H}), 2.03-2.21(\mathrm{~m}, 3 \mathrm{H}), 2.58(\mathrm{~m}, 1 \mathrm{H}), 3.22(\mathrm{t}, J=10.9 \mathrm{~Hz}, 1 \mathrm{H}), 3.41$ $(\mathrm{dt}, J=11.4,3.4 \mathrm{~Hz}, 1 \mathrm{H}), 4.03(\mathrm{dd}, J=6.7,12.4 \mathrm{~Hz}, 1 \mathrm{H}), 4.23-4.39(\mathrm{~m}$, $1 \mathrm{H}), 4.59(\mathrm{~d}, J=11.6 \mathrm{~Hz}, 1 \mathrm{H}), 4.78(\mathrm{~s}, 1 \mathrm{H}), 5.02-5.11(\mathrm{~m}, 1 \mathrm{H}), 5.32-5.43$ $(\mathrm{m}, 3 \mathrm{H}), 5.66-5.68(\mathrm{~m}, 1 \mathrm{H}), 6.01-6.18(\mathrm{~m}, 1 \mathrm{H}), 6.22(\mathrm{~m}, 1 \mathrm{H}), 6.68(\mathrm{~d}, J=$ $11.8 \mathrm{~Hz}, 1 \mathrm{H}), 7.48-7.52(\mathrm{~m}, 3 \mathrm{H}), 7.68(\mathrm{~m}, 1 \mathrm{H}), 7.82(\mathrm{t}, J=7.3 \mathrm{~Hz}, 1 \mathrm{H})$, 7.87-8.02 (m, 3H), $8.17(\mathrm{~d}, J=8.4 \mathrm{~Hz}, 1 \mathrm{H}), 8.90(\mathrm{~d}, J=8.4 \mathrm{~Hz}, 1 \mathrm{H})$, $8.98 \mathrm{ppm}(\mathrm{d}, J=4.5 \mathrm{~Hz}, 1 \mathrm{H}) ;{ }^{13} \mathrm{C} \mathrm{NMR}\left(300 \mathrm{MHz}, \mathrm{CDCl}_{3}\right): \delta=22.7,25.3$, 26.6, 26.9, 37.8, 51.3, 59.6, 62.3, 66.2, 70.3, 118.4, 119.4, 119.9, 124.7, 125.2, $127.1,129.0,129.2,129.9,130.2,130.5,132.5,134.1,136.2,139.9,148.5$, $149.9 \mathrm{ppm} ; \mathrm{MS}$ (ESI): $\mathrm{m} / \mathrm{z}: 425.2[\mathrm{M}+\mathrm{H}]^{+}$.

O-(9)-Allyl-N-9-anthracenylmethylcinchonidinium bromide CTP (7): $:^{[15]}$ M.p. $193^{\circ} \mathrm{C}$ (lit $\left.194-196^{\circ} \mathrm{C}\right) ;{ }^{1} \mathrm{H} \mathrm{NMR}\left(300 \mathrm{MHz}, \mathrm{CDCl}_{3}\right): \delta=1.35-1.54$ $(\mathrm{m}, 2 \mathrm{H}), 1.84-2.05(\mathrm{~m}, 3 \mathrm{H}), 2.12-2.24(\mathrm{~m}, 1 \mathrm{H}), 2.27-2.38(\mathrm{~m}, 1 \mathrm{H}), 2.66$ $(\mathrm{t}, J=10.5 \mathrm{~Hz}, 1 \mathrm{H}), 2.96(\mathrm{t}, J=10.7 \mathrm{~Hz}, 1 \mathrm{H}), 3.41-3.46(\mathrm{~m}, 1 \mathrm{H}), 4.29-$ $4.37(\mathrm{~m}, 1 \mathrm{H}), 4.41-4.55(\mathrm{~m}, 3 \mathrm{H}), 5.03(\mathrm{~d}, J=10.3 \mathrm{~Hz}, 1 \mathrm{H}), 5.16(\mathrm{~d}, J=$ $17.0 \mathrm{~Hz}, 1 \mathrm{H}), 5.51-5.63(\mathrm{~m}, 2 \mathrm{H}), 5.82-5.96(\mathrm{~m}, 2 \mathrm{H}), 6.21-6.36(\mathrm{~m}, 1 \mathrm{H})$, $6.67(\mathrm{~m}, 1 \mathrm{H}), 7.14(\mathrm{~m}, 1 \mathrm{H}), 7.45-7.62(\mathrm{~m}, 4 \mathrm{H}), 7.74-7.84(\mathrm{~m}, 3 \mathrm{H}), 7.99$ $(\mathrm{d}, J=8.2 \mathrm{~Hz}, 1 \mathrm{H}), 8.09$ (d, $J=7.8 \mathrm{~Hz}, 1 \mathrm{H}), 8.17(\mathrm{~d}, J=9.3 \mathrm{~Hz}, 1 \mathrm{H}), 8.23$ $(\mathrm{d}, J=8.6 \mathrm{~Hz}, 1 \mathrm{H}), 8.60(\mathrm{~s}, 1 \mathrm{H}), 9.02(\mathrm{~d}, J=4.4 \mathrm{~Hz}, 1 \mathrm{H}), 9.73 \mathrm{ppm}(\mathrm{d}, J=$ $8.3 \mathrm{~Hz}, 1 \mathrm{H}) ;{ }^{13} \mathrm{C}$ NMR $\left(300 \mathrm{MHz}, \mathrm{CDCl}_{3}\right): \delta=23.4,25.6,26.1,38.3,50.1$, $51.1,55.1,61.5,65.7,70.3,117.9,118.1,118.5,123.3,125.0,125.5,126.7$, $127.8,128.3,129.0,130.1,130.8,130.9,131.2,132.2,132.7,133.2,133.6$, 136.7, 139.8, 148.6, 149.9 ppm; MS (ESI): $m / z: 526.4[M+\mathrm{H}]^{+}$.

General procedure for the alkylation reaction: Compound $2(0.3 \mathrm{mmol}$, $88,5 \mathrm{mg}$ ) was added to a $5 \mathrm{~mL}$ grinding jar containing two $5 \mathrm{~mm}$ stainless steel balls, then $\mathrm{KOH}(0.6 \mathrm{mmol}, 34 \mathrm{mg}, 2$ equiv $)$, the catalyst $(0.03 \mathrm{mmol}, 10 \mathrm{~mol} \%)$, and finally the alkylating reagent $(0.3 \mathrm{mmol}$, 1 equiv) were added. The reactants were ball milled at the specified frequency for the corresponding time to achieve complete conversion. $\mathrm{Et}_{2} \mathrm{O}$ $(5 \mathrm{~mL})$ was added to recover the crude mixture, and the solution was washed with water $(3 \times 5 \mathrm{~mL})$, dried, and concentrated in vacuo to obtain the desired product. The aqueous layer was extracted with $\mathrm{CH}_{2} \mathrm{Cl}_{2}$ to recover the catalyst. 
(S)-tert-Butyl-2-(diphenylmethyleneamino)pent-4-enoate (8) [119244-223]: ${ }^{[20]}$ Yield: $97.3 \mathrm{mg}(97 \%)$; colorless oil; $[\alpha]_{\mathrm{D}}^{20}=-40\left(c=2, \mathrm{CHCl}_{3}\right) ; e e=$ $75 \%$ (HPLC analysis of the Marfey derivative: $\left.t_{\mathrm{r}}=7.6(S), 7.9 \mathrm{~min}(R)\right]$; ${ }^{1} \mathrm{H}$ NMR $\left(300 \mathrm{MHz}, \mathrm{CDCl}_{3}\right): \delta=1.36(\mathrm{~s}, 9 \mathrm{H}), 2.51-2.59(\mathrm{~m}, 2 \mathrm{H}), 3.93$ $(\mathrm{dd}, J=5.5,7.5 \mathrm{~Hz}, 1 \mathrm{H}), 4.93(\mathrm{~d}, J=10.2 \mathrm{~Hz}, 1 \mathrm{H}), 5.00(\mathrm{~d}, J=18.2 \mathrm{~Hz}$, 1 H), 5.56-5.72 (m, 1 H), 7.04-7.14 (m, 2H), 7.19-7.33 (m, 2H), 7.35-7.48 $(\mathrm{m}, 3 \mathrm{H}), 7.57(\mathrm{~d}, J=7.8 \mathrm{~Hz}, 2 \mathrm{H}), 7.73 \mathrm{ppm}(\mathrm{d}, J=7.0 \mathrm{~Hz}, 1 \mathrm{H}) ;{ }^{13} \mathrm{C} \mathrm{NMR}$ $\left(300 \mathrm{MHz}, \mathrm{CDCl}_{3}\right): \delta=28.8,38.8,66.5,81.7,118.0,128.6,128.7,129.0$, $129.1,129.2,129.5,130.8,130.9,133.1,135.4,138.3,140.4,170.8$, $171.6 \mathrm{ppm} ; \mathrm{MS}$ (ESI): $m / z: 336.3[M+\mathrm{H}]^{+}, 280.2$.

(S,E)-tert-Butyl-2-(diphenylmethyleneamino)hex-4-enoate (9) [486406-386]: ${ }^{[21]}$ Yield: $96 \mathrm{mg}(92 \%)$; colorless oil; $[\alpha]_{\mathrm{D}}^{20}=-20\left(c=1, \mathrm{CHCl}_{3}\right) ; e e=$ $66 \%$ (HPLC analysis of the Marfey derivative: $t_{\mathrm{r}}=8.1(S), 8.4 \mathrm{~min}(R)$ ); ${ }^{1} \mathrm{H}$ NMR $\left(300 \mathrm{MHz}, \mathrm{CDCl}_{3}\right): \delta=1.36(\mathrm{~s}, 9 \mathrm{H}), 1.53(\mathrm{~d}, J=6.3 \mathrm{~Hz}, 3 \mathrm{H})$, 2.32-2.54 (m, 2H), $3.88(\mathrm{dd}, J=5.6,7.6 \mathrm{~Hz}, 1 \mathrm{H}), 5.13-5.29(\mathrm{~m}, 1 \mathrm{H})$, 5.31-5.47 (m, 1H), 7.02-7.11 (m, 2H), 7.16-7.36 (m, 6H), $7.56 \mathrm{ppm}(\mathrm{d}$, $J=6.9 \mathrm{~Hz}, 2 \mathrm{H}) ;{ }^{13} \mathrm{C} \mathrm{NMR}\left(300 \mathrm{MHz}, \mathrm{CDCl}_{3}\right): \delta=17.8,27.9,36.8,66.2$, 80.7, 126.9, 127.6, 127.8, 127.9, 128.2, 128.6, 129.9, 136.6, 139.7, 169.7, $170.9 \mathrm{ppm} ; \mathrm{MS}$ (ESI): $m / z: 350.3[M+\mathrm{H}]^{+}, 294.3$.

(S)-tert-Butyl-2-(diphenylmethyleneamino)-4-methylpent-4-enoate (10) [200132-62-3]: ${ }^{[22]}$ Yield: $97 \mathrm{mg}(93 \%)$; colorless oil; $[\alpha]_{\mathrm{D}}^{20}=-33(c=1$, $\mathrm{CHCl}_{3}$ ) $; e e=61 \%$ (HPLC analysis of the Marfey derivative: $t_{\mathrm{r}}=8.0(S)$, $8.3 \mathrm{~min}(R)) ;{ }^{1} \mathrm{H} \mathrm{NMR}\left(300 \mathrm{MHz}, \mathrm{CDCl}_{3}\right): \delta=1.36(\mathrm{~s}, 9 \mathrm{H}), 1.43(\mathrm{~s}, 3 \mathrm{H})$, $2.48-2.55(\mathrm{~m}, 2 \mathrm{H}), 4.00(\mathrm{dd}, J=5.3,8.1 \mathrm{~Hz}, 1 \mathrm{H}), 4.64(\mathrm{~d}, J=6.0 \mathrm{~Hz}, 1 \mathrm{H})$, 7.06-7.11 (m, 2H), 7.16-7.36 (m, 6H), $7.55 \mathrm{ppm}(\mathrm{d}, J=6.7 \mathrm{~Hz}, 2 \mathrm{H})$; ${ }^{13} \mathrm{C} \mathrm{NMR}\left(300 \mathrm{MHz}, \mathrm{CDCl}_{3}\right): \delta=20.3,25.8,39.6,62.5,78.5,111.1,125.7$, 125.8, 126.0, 126.2, 126.5, 127.8, 134.2, 137.5, 139.6, 167.6, 168.9 ppm; MS (ESI): $m / z: 350.3[M+\mathrm{H}]^{+}, 294.3$.

(S)-tert-Butyl-4-bromo-2-(diphenylmethylene amino)pent-4-enoate (11) [583827-73-6]: Yield: $117 \mathrm{mg}(95 \%)$; colorless oil; $[\alpha]_{\mathrm{D}}^{20}=-113(c=1$, $\mathrm{CHCl}_{3}$ );ee $=71 \%$ (HPLC analysis of the Marfey derivative: $t_{\mathrm{r}}=7.9(S)$, $8.3 \mathrm{~min}(R)) ;{ }^{1} \mathrm{H}$ NMR $\left(300 \mathrm{MHz}, \mathrm{CDCl}_{3}\right): \delta=1.49(\mathrm{~s}, 9 \mathrm{H}), 3.05-3.12(\mathrm{~m}$, $2 \mathrm{H}), 4.30(\mathrm{dd}, J=5.1,8.0 \mathrm{~Hz}, 1 \mathrm{H}), 5.46(\mathrm{~s}, 1 \mathrm{H}), 5.73(\mathrm{~s}, 1 \mathrm{H}), 7.25-7.30$ $(\mathrm{m}, 2 \mathrm{H}), 7.32-7.44(\mathrm{~m}, 3 \mathrm{H}), 7.47-7.52(\mathrm{~m}, 3 \mathrm{H}), 7.66 \mathrm{ppm}(\mathrm{d}, J=6.0 \mathrm{~Hz}$, $1 \mathrm{H}) ;{ }^{13} \mathrm{C} \mathrm{NMR}\left(300 \mathrm{MHz}, \mathrm{CDCl}_{3}\right): \delta=28.1,45.6,63.9,81.6,119.7,128.0$, 128.2, 128.3, 128.7, 128.9, 130.2, 136.2, 139.7, 170.1, 171.4 ppm; MS (ESI): $m / z: 416.1[M+\mathrm{H}]^{+}, 414.1[M+\mathrm{H}]^{+}, 360.1,358.1$; HRMS: $m / z$ : calcd for $\mathrm{C}_{22} \mathrm{H}_{25} \mathrm{NO}_{2} \mathrm{Br}$ : 414.1069; found: 414.1072.

(S)-tert-Butyl-2-(diphenylmethyleneamino)-3-phenylpropanoate (12) [119244-23-4]:[20] Yield: $110 \mathrm{mg}(96 \%) ;[\alpha]_{\mathrm{D}}^{20}=-113\left(c=2, \mathrm{CHCl}_{3}\right) ; e e=$ $59 \%$ (HPLC analysis of the Marfey derivative: $t_{\mathrm{r}}=8.4(S), 8.7 \mathrm{~min}(R)$ ); ${ }^{1} \mathrm{H}$ NMR $\left(300 \mathrm{MHz}, \mathrm{CDCl}_{3}\right): \delta=1.35(\mathrm{~s}, 9 \mathrm{H}), 3.02-3.20(\mathrm{~m}, 2 \mathrm{H}), 4.03$ $(\mathrm{dd}, J=4.5,9.0 \mathrm{~Hz}, 1 \mathrm{H}), 6.51(\mathrm{~d}, J=6.7 \mathrm{~Hz}, 1 \mathrm{H}), 6.90-6.99(\mathrm{~m}, 3 \mathrm{H})$, 7.03-7.09 (m, 3H), 7.15-7.27 (m, 6H), $7.49 \mathrm{ppm}(\mathrm{d}, J=6.7 \mathrm{~Hz}, 2 \mathrm{H})$; ${ }^{13} \mathrm{C}$ NMR $\left(300 \mathrm{MHz}, \mathrm{CDCl}_{3}\right): \delta=28.6,40.1,68.5,81.6,126.7,128.2,128.4$, $128.5,128.6,128.7,129.2,130.4,130.6,136.9,138.9,140.1,170.8$, $171.3 \mathrm{ppm} ; \mathrm{MS}$ (ESI): $m / z: 386.0[M+\mathrm{H}]^{+}, 330.2$.

(S)-tert-Butyl-2-(diphenylmethyleneamino)-3-(naphthalen-2-yl)propanoate (13) $[119244-29-0]:{ }^{[20]}$ Yield: $124 \mathrm{mg}(95 \%)$; pale-yellow oil; $[\alpha]_{\mathrm{D}}^{20}=-58$ $\left(c=1, \mathrm{CHCl}_{3}\right) ; e e=75 \%$ (HPLC analysis of the Marfey derivative: $t_{\mathrm{r}}=$ $9.9(S), 10.3 \mathrm{~min}(R)) ;{ }^{1} \mathrm{H} \mathrm{NMR}\left(300 \mathrm{MHz}, \mathrm{CDCl}_{3}\right): \delta=1.36(\mathrm{~s}, 9 \mathrm{H})$, $3.20-3.35(\mathrm{~m}, 2 \mathrm{H}), 4.16(\mathrm{dd}, J=4.4,9.0 \mathrm{~Hz}, 1 \mathrm{H}), 7.01-7.13(\mathrm{~m}, 3 \mathrm{H})$, $7.18-7.27(\mathrm{~m}, 4 \mathrm{H}), 7.29-7.52(\mathrm{~m}, 6 \mathrm{H}), 7.58(\mathrm{~d}, J=7.9 \mathrm{~Hz}, 2 \mathrm{H}), 7.62-$ $7.78 \mathrm{ppm}(\mathrm{m}, 2 \mathrm{H}) ;{ }^{13} \mathrm{C} \mathrm{NMR}\left(300 \mathrm{MHz}, \mathrm{CDCl}_{3}\right): \delta=28.1,39.8,67.9,81.2$, $125.3,125.8,127.5,127.6,127.7,128.0,128.1,128.3,128.4,128.8,130.2$, $132.2,133.5,136.0,136.3,139.6,170.5,170.9 \mathrm{ppm}$; MS (ESI): $m / z: 436.0$ $[M+\mathrm{H}]^{+}$.

(S)-tert-Butyl-2-(diphenylmethyleneamino)pent-4-ynoate (14) [32666754-3]: ${ }^{[20]}$ Yield: $92 \mathrm{mg}(92 \%)$; colorless oil; $[\alpha]_{\mathrm{D}}^{20}=-30\left(c=2, \mathrm{CHCl}_{3}\right)$; $e e=70 \%$ (HPLC analysis of the Marfey derivative: $t_{\mathrm{r}}=7.2(S), 7.4 \mathrm{~min}$ $(R)) ;{ }^{1} \mathrm{H}$ NMR $\left(300 \mathrm{MHz}, \mathrm{CDCl}_{3}\right): \delta=1.36(\mathrm{~s}, 9 \mathrm{H}), 1.86(\mathrm{t}, J=2.6 \mathrm{~Hz}$, $1 \mathrm{H}), 2.65-2.73(\mathrm{~m}, 2 \mathrm{H}), 4.10(\mathrm{dd}, J=5.3,8.5 \mathrm{~Hz}, 1 \mathrm{H}), 7.12-7.45(\mathrm{~m}, 6 \mathrm{H})$, $7.59(\mathrm{~m}, 2 \mathrm{H}), 7.72 \mathrm{ppm}(\mathrm{m}, 2 \mathrm{H}) ;{ }^{13} \mathrm{C} \mathrm{NMR}\left(300 \mathrm{MHz}, \mathrm{CDCl}_{3}\right): \delta=23.4$, 28.0, 64.8, 70.1, 81.2, 81.6, 128.0, 128.2, 128.3, 128.4, 128.7, 129.0, 130.0, $130.4,132.4,136.3,137.6,139.6,169.6,171.4 \mathrm{ppm}$; MS (ESI): $\mathrm{m} / \mathrm{z}: 334.3$ $[M+\mathrm{H}]^{+}, 278.2$.

(S)-tert-Butyl-4-cyano-2-(diphenylmethyleneamino)butanoate

[271601-28-6]: ${ }^{[23]}$ Yield: $98 \mathrm{mg}(94 \%)$; yellow oil; $[\alpha]_{\mathrm{D}}^{20}=-29 \quad(c=1$,
$\mathrm{CHCl}_{3}$ );ee $=42 \%$ (HPLC analysis of the Marfey derivative: $t_{\mathrm{r}}=8.8(S)$, $9.1 \mathrm{~min}(R)) ;{ }^{1} \mathrm{H}$ NMR $\left(300 \mathrm{MHz}, \mathrm{CDCl}_{3}\right): \delta=1.47(\mathrm{~s}, 9 \mathrm{H}), 2.18-2.31(\mathrm{~m}$, $2 \mathrm{H}), 2.46-2.53(\mathrm{~m}, 2 \mathrm{H}), 4.08(\mathrm{dd}, J=4.7,7.7 \mathrm{~Hz}, 1 \mathrm{H}), 7.19-7.25(\mathrm{~m}, 2 \mathrm{H})$ $7.32-7.43(\mathrm{~m}, 3 \mathrm{H}), 7.48-7.52(\mathrm{~m}, 3 \mathrm{H}), 7.69 \mathrm{ppm}(\mathrm{d}, J=7.8 \mathrm{~Hz}, 2 \mathrm{H})$ ${ }^{13} \mathrm{C}$ NMR $\left(300 \mathrm{MHz}, \mathrm{CDCl}_{3}\right.$ ): $\delta=28.1,45.6,63.9,81.6,119.7,128.0,128.3$, $128.7,128.9,130.2,136.2,139.7,170.1,171.4 \mathrm{ppm}$; MS (ESI): $\mathrm{m} / \mathrm{z}: 349.1$ $[M+\mathrm{H}]^{+}, 293.3$.

(S)-tert-Butyl-2-(diphenylmethyleneamino)-3-(2-iodophenyl)propanoate (16): Yield: $139 \mathrm{mg}(91 \%)$; colorless oil; $[\alpha]_{\mathrm{D}}^{20}=-149\left(c=2, \mathrm{CHCl}_{3}\right) ; e e=$ $59 \%$ (HPLC analysis of the Marfey derivative: $t_{\mathrm{r}}=8.9(S), 9.2 \mathrm{~min}(R)$ ); ${ }^{1} \mathrm{H}$ NMR $\left(300 \mathrm{MHz}, \mathrm{CDCl}_{3}\right): \delta=1.50(\mathrm{~s}, 9 \mathrm{H}), 3.18-3.50(\mathrm{~m}, 2 \mathrm{H}), 4.39$ $(\mathrm{dd}, J=3.9,9.8 \mathrm{~Hz}, 1 \mathrm{H}), 6.59(\mathrm{~d}, J=6.7 \mathrm{~Hz}, 2 \mathrm{H}), 6.87(\mathrm{dd}, J=0.9,1.1 \mathrm{~Hz}$, $1 \mathrm{H}), 7.18-7.22(\mathrm{~m}, 2 \mathrm{H}), 7.26-7.42(\mathrm{~m}, 6 \mathrm{H}), 7.64(\mathrm{~d}, J=8.0 \mathrm{~Hz}, 2 \mathrm{H})$, $7.79 \mathrm{ppm}(\mathrm{d}, J=7.6 \mathrm{~Hz}, 1 \mathrm{H}) ;{ }^{13} \mathrm{C}$ NMR $\left(300 \mathrm{MHz}, \mathrm{CDCl}_{3}\right): \delta=28.1,43.9$, 65.2, 81.2, 101.4, 127.7, 127.8, 128.0, 128.2, 1283, 128.8, 130.1, 130.2, 132.1, $136.2,139.2,139.4,140.7,170.6,170.8 \mathrm{ppm} ; \mathrm{MS}$ (ESI): $\mathrm{m} / \mathrm{z}: 511.9$ $[M+\mathrm{H}]^{+}, 456.1$; HRMS: $m / z$ : calcd for $\mathrm{C}_{26} \mathrm{H}_{27} \mathrm{NO}_{2} \mathrm{I}$ : 512.1087; found: 512.1091 .

(S)-tert-Butyl-3-(2-bromo-5-fluorophenyl)-2-(diphenylmethyleneamino)propanoate (17): Yield: $138 \mathrm{mg}(96 \%)$; colorless oil; $[\alpha]_{\mathrm{D}}^{20}=-102(c=1$, $\mathrm{CHCl}_{3}$ );ee $=53 \%$ (HPLC analysis of the Marfey derivative: $t_{\mathrm{r}}=8.8(S)$, $9.1 \mathrm{~min}(R)) ;{ }^{1} \mathrm{H}$ NMR $\left(300 \mathrm{MHz}, \mathrm{CDCl}_{3}\right): \delta=1.49(\mathrm{~s}, 9 \mathrm{H}), 3.27$ (dd, $J=$ 9.3, $13.4 \mathrm{~Hz}, 1 \mathrm{H}), 3.45(\mathrm{dd}, J=4.4,13.4 \mathrm{~Hz}, 1 \mathrm{H}), 4.38(\mathrm{dd}, J=4.4,9.3 \mathrm{~Hz}$, $1 \mathrm{H}), 6.72-6.85(\mathrm{~m}, 3 \mathrm{H}), 7.00(\mathrm{dd}, J=3.0,9.4 \mathrm{~Hz}, 1 \mathrm{H}), 7.29-7.47(\mathrm{~m}, 7 \mathrm{H})$, 7.59-7.68 ppm (m, 2 H) ; ${ }^{13} \mathrm{C}$ NMR (300 $\left.\mathrm{MHz}, \mathrm{CDCl}_{3}\right): \delta=28.0,39.7,65.0$, $81.4,115.2(\mathrm{~d}, J=21.9 \mathrm{~Hz}), 119.4(\mathrm{~d}, J=22.6 \mathrm{~Hz}), 127.7,128.0,128.2$ $128.5,128.8,133.5(\mathrm{~d}, J=7.5 \mathrm{~Hz}), 136.1,139.3,139.8(\mathrm{~d}, J=7.5 \mathrm{~Hz}), 159.8$, 163.1, 170.3, $171.0 \mathrm{ppm}$; MS (ESI): $\mathrm{m} / z: 482.2[\mathrm{M}+\mathrm{H}]^{+}, 484.2[\mathrm{M}+\mathrm{H}]^{+}$; HRMS: $m / z$ : calcd. for $\mathrm{C}_{26} \mathrm{H}_{26} \mathrm{NO}_{2} \mathrm{BrF}$ : 482.1131 ; found: 482.1129 .

(S)-tert-Butyl 2-(diphenylmethyleneamino)-4-(2-methoxyethoxy)butanoate (18): Yield: $110 \mathrm{mg}(93 \%)$; colorless oil; $[\alpha]_{\mathrm{D}}^{20}=-26\left(c=1, \mathrm{CHCl}_{3}\right) ; e e=$ $36 \%$ (HPLC analysis of the Marfey derivative: $t_{\mathrm{r}}=7.0(S), 7.2 \mathrm{~min}(R)$ ) ${ }^{1} \mathrm{H}$ NMR $\left(300 \mathrm{MHz}, \mathrm{CDCl}_{3}\right): \delta=1.45(\mathrm{~s}, 9 \mathrm{H}), 2.17-2.32(\mathrm{~m}, 2 \mathrm{H}), 3.35(\mathrm{~s}$ $3 \mathrm{H}), 3.43-3.55(\mathrm{~m}, 6 \mathrm{~Hz}), 4.13(\mathrm{dd}, J=4.7,8.3 \mathrm{~Hz}, 1 \mathrm{H}), 7.17-7.23(\mathrm{~m}$ $2 \mathrm{H}), 7.28-7.55(\mathrm{~m}, 9 \mathrm{H}), 7.65(\mathrm{~d}, J=6.9 \mathrm{~Hz}, 2 \mathrm{H}), 7.83 \mathrm{ppm}(\mathrm{d}, J=9.0 \mathrm{~Hz}$, $1 \mathrm{H}) ;{ }^{13} \mathrm{C} \mathrm{NMR}\left(300 \mathrm{MHz}, \mathrm{CDCl}_{3}\right): \delta=27.6,33.0,58.6,62.5,67.5,69.6$, $71.4,80.6,127.5,127.6,127.9,128.1,128.4,129.7,129.8,132.0,136.2$, 139.3, 170.2, $170.8 \mathrm{ppm}$; MS (ESI): $m / z: 398.1[M+\mathrm{H}]^{+}, 183.1$; HRMS $m / z$ : calcd for $\mathrm{C}_{24} \mathrm{H}_{32} \mathrm{NO}_{4}$ : 398.2331 ; found: 398.2328 .

General procedure for the derivatization with Marfey's reagent: The alkylated products $\mathbf{3}-\mathbf{1 3}$ were dissolved in $\mathrm{Et}_{2} \mathrm{O}(2 \mathrm{~mL})$ and an aqueous solution of $1 \mathrm{~N} \mathrm{HCl}(2 \mathrm{~mL})$ was added. The mixture was stirred magnetical ly at RT overnight, the aqueous layer was washed with $\mathrm{Et}_{2} \mathrm{O}(2 \times 2 \mathrm{~mL})$ and evaporated to obtain the amino acid hydrochloride as a solid. Four solutions were then prepared: Solution 1 [amino acid $(10 \mathrm{mg})$ in water $(1.3 \mathrm{~mL}$ ], Solution 2 [Marfey's reagent $(50 \mathrm{mg})$ in acetone $(5 \mathrm{~mL})$ ], Solution 3 (aqueous solution of $1 \mathrm{M} \mathrm{NaHCO}_{3}$ ), and Solution $4(1 \mathrm{~N} \mathrm{HCl})$. Solution $2(200 \mu \mathrm{L})$ and Solution $3(60 \mu \mathrm{L})$ were then added to Solution 1 $(100 \mu \mathrm{L})$ and the mixture was stirred for $1 \mathrm{~h}$ at $40^{\circ} \mathrm{C}$, cooled to RT and then Solution $4(60 \mu \mathrm{L})$ was added. The resulting mixture was analyzed at $340 \mathrm{~nm}$ using a Symmetry Shield column, with a linear gradient of acetonitrile in water, from 0 to $100 \%$ in $20 \mathrm{~min}$.

\section{Acknowledgements}

We thank the CNRS and the MENRT for financial support. P. N. thanks The Fondation d'Entreprise EADS for a fellowship. Technical support from Retsch Gmbh is also acknowledged.

[1] V. A. Soloshonok, K. Izawa, Asymmetric Synthesis and Application of alpha-Amino Acids, ACS Symposium Series, 2009.

[2] M. J. O’Donnell, J. M. Boniece, S. E. Earp, Tetrahedron Lett. 1978 , 2641.

[3] M. J. O’Donnell, W. D. Bennett, S. Wu, J. Am. Chem. Soc. 1989, 111, 2353. 
[4] a) M. J. O'Donnell, Acc. Chem. Res. 2004, 37, 506; b) B. Lygo, B. I. Andrews, Acc. Chem. Res. 2004, 37, 518; c) A. Berkessel, H. Gröger, Asymmetric Organocatalysis, Wiley-VCH, Weinheim, 2005; d) T. Ooi in Asymmetric Phase Transfer Catalysis (Ed.: K. Maruoka), Wiley-VCH, Weinheim, 2008, p. 9; e) T. Hashimoto, K. Maruoka, Chem. Rev. 2007, 107, 5656.

[5] K. Maruoka, Org. Process Res. Dev. 2008, 12, 679

[6] a) G. Kaupp, M. R. Naimi-Jamal, H. Ren, H. Zoz in Technologies Based on Self-Propagating and Mechanochemical Reactions for Environmental Protection (Eds.: G. Cao, F. Delogu, R. Orrù), Research Signpost, Kerala, 2003; b) S. Kipp, V. Sepelàk, K. D. Becker, Chem. Unserer Zeit 005, 39, 384; c) S. L. James, C. J. Adams, C. Bolm, D. Braga, P. Collier, T. Friščic, F. Grepioni, K. D. M. Harris, G. Hyett, W. Jones, A. Krebs, J. Mack, L. Maini, A. G. Orpen, I. P. Parkin, W. C. Shearouse, J. W. Steed, D. C. Waddell, Chem. Soc. Rev. 2012, $41,413$.

[7] a) G. Kaupp, Top. Curr. Chem. 2005, 254, 95; b) B. Rodriguez, A Bruckmann, T. Rantanen, C. Bolm, Adv. Synth. Catal. 2007, 349, 2213; c) A. Stolle, T. Szuppa, S. E. S. Leonhardt, B. Ondruschka, Chem. Soc. Rev. 2011, 40, 2317; d) A. Bruckmann, A. Krebs, C. Bolm, Green Chem. 2008, 10, 1131.

[8] a) V. Declerck, P. Nun, J. Martinez, F. Lamaty, Angew. Chem. 2009, 121, 9482; Angew. Chem. Int. Ed. 2009, 48, 9318; b) A. Baron, J. Martinez, F. Lamaty, Tetrahedron Lett. 2010, 51, 6246.

[9] a) B. Rodriguez, T. Rantanen, C. Bolm, Angew. Chem. 2006, 118, 7078; Angew. Chem. Int. Ed. 2006, 45, 6924; b) T. Rantanen, I. Schiffers, C. Bolm, Org. Process Res. Dev. 2007, 11, 592; c) B. Rodriguez, A. Bruckmann, C. Bolm, Chem. Eur. J. 2007, 13, 4710; d) A. Bruckmann, B. Rodriguez, C. Bolm, CrystEngComm 2009, 11, 404; e) G. Guillena, M. d. C. Hita, C. Najera, S. F. Viozquez, J. Org. Chem. 2008, 73, 5933.

[10] a) K. J. Fasth, G. Antoni, B. Längström, J. Chem. Soc. Perkin Trans. 1 1988, 3081; b) M. Selva, P. Tundo, C. A. Marques, Synth. Comm. 1995, 25, 369
[11] M. J. O’Donnell, R. L. Polt, J. Org. Chem. 1982, 47, 2663.

[12] M. J. O'Donnell, I. A. Esikova, A. Mi, D. F. Shullenberger, S. Wu in Phase Transfer Catalysis, Mechanism and Syntheses, (Ed.: M. H. Halpern), ACS Symposium Series 659, Washington DC, 1996, pp. 124 135

[13] D. C. Waddell, I. Thiel, T. D. Clark, S. T. Marcum, J. Mack, Green Chem. 2010, 12, 209.

[14] a) M. J. O’Donnell, W. D. Bennett, W. A. Bruder, W. N. Jacobsen, K. Knuth, B. LeClef, R. L. Polt, F. G. Bordwell, S. R. Mrozack, T. A Cripe, J. Am. Chem. Soc. 1988, 110, 8520; b) M. J. O'Donnell, W. D Bennett, W. N. Jacobsen, Y. Ma, J. C. Huffman, Tetrahedron Lett. 1989, 30, 3909.

[15] E. J. Corey, F. Xu, M. C. Noe, J. Am. Chem. Soc. 1997, 119, 12414.

[16] P. Marfey, Carlsberg Res. Commun. 1984, 49, 591.

[17] S. E. Denmark, N. D. Gould, L. M. Wolf, J. Org. Chem. 2011, 76, 4260.

[18] T. Tozawa, H. Nagao, Y. Yamane, T. Mukaiyama, Chem. Asian J. 2007, 2, 123

[19] M. Matsushita, K. Yoshida, N. Yamamoto, P. Wirsching, R. A Lerner, K. D. Janda, Angew. Chem. 2003, 115, 6166; Angew. Chem. Int. Ed. 2003, 42, 5984.

[20] T. Okino, Y. Takemoto, Org. Lett. 2001, 3, 1515.

[21] T. Kita, A. Georgieva, Y. Hashimoto, T. Nakata, K. Nagasawa, Angew. Chem. 2002, 114, 2956; Angew. Chem. Int. Ed. 2002, 41, 2832.

[22] B. Lygo, J. Crosby, T. R. Lowdon, P. G. Wainwright, Tetrahedron 2001, 57, 2391.

[23] F.-Y. Zhang, E. J. Corey, Org. Lett. 2000, 2, 1097. 